\title{
Bazı organik materyallerin ve inorganik gübrelerin çemenin (trigonella foenum graecum) besin elementi içeriğine etkileri
}

\section{Effects of some organic materials and inorganic fertilizers on nutrient contents of fenigreek (trigonella foenum graecum)}

\author{
Veysi AKŞAHIN ${ }^{1}$, Füsun GÜLSER ${ }^{2}$ i \\ ${ }^{1}$ Çukurova Üniversitesi, Ziraat Fakültesi, Toprak Bilimi ve Bitki Besleme Bölümü, Adana \\ ${ }^{2}$ Van Yüzüncü Yıl Üniversitesi, Ziraat Fakültesi, Toprak Bilimi ve Bitki Besleme Bölümü, Van \\ Sorumlu yazar (Corresponding author): F. Gülser, e-posta (e-mail): fgulser@yyu.edu.tr \\ Yazar(lar) e-posta (Author e-mail): veysiaksahin@gmail.com
}

\section{MAKALE BİLGISİ}

Alınış tarihi 12 Mart 2019

Düzeltilme tarihi 19 Nisan 2019

Kabul tarihi 26 Nisan 2019

\section{Anahtar Kelimeler:}

Atık mantar kompostu

Çay atı̆̆

İnorganik gübre

Çemen

Besin elementi

\begin{abstract}
$\ddot{0 Z Z}$
Bu çalışmada çay atığı (ÇA) ve atık mantar kompostu (AMK) ile inorganik gübrelerin (İG) çemen (Trigonella Foenum Graecum) bitkisinin besin elementi içeriğine etkilerinin araştırılması amaçlanmıştır. Deneme faktöriyel deneme desenine göre üç tekrarlamalı olarak 54 saksıda yürütülmüşstür. Araştırmada çay atığı $(\% 0, \% 2.5$ ve $\% 5.0)$ ve atık mantar kompostu $\left(\% 0, \% 2.5\right.$ ve \%5.0) üç farklı dozda uygulanmıştır. Amonyum sülfat $\left(0,125,250 \mathrm{mg} \mathrm{N} \mathrm{kg}^{-1}\right)$ triple süper fosfat $\left(0,50,100 \mathrm{mg} \mathrm{P}_{2} \mathrm{O}_{5} \mathrm{~kg}^{-1}\right)$ ve potasyum sülfatın $\left(0,75,150 \mathrm{mg} \mathrm{K}_{2} \mathrm{O} \mathrm{kg}^{-1}\right)$ üc farklı dozu inorganik gübre olarak kullanılmıştır. Organik materyal çeşidi, ÇA, AMK, İG dozları ve bunların interaksiyonlarının $\mathrm{N}, \mathrm{P}, \mathrm{Fe}$ ve $\mathrm{Zn}$ içerikleri üzerine etkileri genel olarak istatistiksel anlamda önemli bulunmuștur. En yüksek N (\%5.43), Fe (613 mg kg-1) ve Zn (95 $\mathrm{mg} \mathrm{kg}^{-1}$ ) ortalamaları siras ile AMK0xÍG0 ve AMK0xíG1 uygulamalarında elde edilmișlerdir. En yüksek $\mathrm{P}$ ortalaması ise $\% 0.43$ olarak AMK2xÍG2 uygulamasında belirlenmiştir. Genel olarak AMK uygulamalarında elde edilen besin elementi ortalamaları ÇA uygulamalarında elde edilenlerden daha yüksek bulunmuştur. İG uygulamaları ise bitkinin $\mathrm{N}$, $\mathrm{P}$ ve $\mathrm{Mn}$ içeriklerini arttırmıștır.
\end{abstract}

\section{ARTICLE INFO}

Received 12 March 2019

Received in revised form 19 April 2019 Accepted 26 April 2019

Keywords:

Spent mushroom compost

Tea waste

Inorganic fertilizer

Fenigreek

Nutrient

\begin{abstract}
In this study determination of effects of tea waste (TW), spent mashroom compost (SMC) and inorganic fertilizers (IF) on nutrient contents of fenigreek (Trigonella Foenum Graecum) was aimed. The experiment was carried out according to factorial experiment and with three replication in 54 pots. Tea waste $(0,2.5,5.0 \%)$ and spent mashroom compost $(0,2.5,5.0 \%)$ were applied at three different doses of ammonium sulphate $\left(0,125,250 \mathrm{mg} \mathrm{N} \mathrm{kg}^{-1}\right)$ Triple süper phosphate $\left(0,50,100 \mathrm{mg} \mathrm{P}_{2} \mathrm{O}_{5} \mathrm{~kg}^{-1}\right)$ and potassium sulphate $\left(0,75,150 \mathrm{mg} \mathrm{K} \mathrm{O} \mathrm{kg}^{-1}\right)$ were used. Effects of organic material type, TW, SMC, IF doses and their interactions on N, P, $\mathrm{Fe}$ and $\mathrm{Zn}$ contents were found generally significant statistically. The highest $\mathrm{N}(5.43 \%), \mathrm{Fe}$ (613 mg kg-1) and $\mathrm{Zn}\left(95 \mathrm{mg} \mathrm{kg}^{-1}\right)$ means were found in SMC 0 IF 0 and SMC 0 IF 1 applications respectively. The highest $\mathrm{P}$ means were obtained as $0.43 \%$ in SMC 2 IF 2 applications. Generally, the means of nutrients obtained in SMC applications were found as higher than those obtained in the TW applications. Inorganic fertilizers applications increased $\mathrm{N}, \mathrm{P}$ and Mn contens of plant.
\end{abstract}

\section{Giriş}

Dünya pazarlarında tıbbi ve aromatik bitkilere olan talep her geçen gün giderek artmaktadır. Türkiye, tıbbi ve aromatik bitkiler bakımından dünyanın en zengin ülkelerinden biridir. Ülkemiz farklı iklim ve ekolojik koşullara sahip olması, floranın çok sayıda bitki türü ve çeşitliliği içermesi bakımından doğadan toplanan ve kültürü yapılan tıbbi ve aromatik bitkiler bakımından büyük bir ekonomik potansiyele sahiptir. Türkiye, tıbbi ve aromatik bitkilerin dış satımında da dünyanın önde gelen ülkeleri arasında yer almaktadır. Tıbbi bitkilerin bazı türlerinde doğadan toplama ekonomik olsa da bu şekilde toplanan bitkilerde kaliteli ve standart ürün elde etmede zorluklar ortaya çıkmaktadır. Doğadan toplanan bitkilerde kalitenin her zaman istenen düzeyde olmaması, toplama sonras1 işleme, depolama ve nakliye koşullarının yeterince 
karşılanamaması gibi nedenler ile esas olan bu bitkilerin tarımının yaygınlaştırılmasıdır (Bayram ve ark. 2010).

Dünyada yaygın olarak bulunan fesleğen, çemen, rezene, anason, haşhaş, kimyon, kişniş, safran, defne gibi önemli tıbbi aromatik bitkilerin ülkemizde kültürü yapılmaktadır. Çemen bu bitkiler içerisinde önemli bir yere sahiptir (Beyni 2011). Çemen bitkisi, Fabaceae familyasına ait tek yıllık bir baklagil bitkisidir. Çemen bitkisi, kurağa ve yüksek sıcaklığa dayanıklı, 1lıman iklimlerde iyi gelişen ve kışlık olarak ekilebilen bir bitkidir. (Kevseroğlu ve Özyazıc1 1997; Kızıl ve Arslan 2003). Çemenin tahriş giderici, sindirimi kolaylaştırıcı, ateş düşürücü, kan şekerini düşürücü vb. etkileri yanında, kanser tedavisinde de kullanıldığı bildirilmektedir (Hornok 1992; Abdelgani ve ark. 1998).

İnorganik gübrelerin dünya bitki üretiminde ve günümüz tarımında önemli etkileri olduğu bildirilmiş (Fixon ve West 2002) olmakla birlikte, çevre üzerindeki olumsuz etkileri ve yüksek fiyatları dolayısı ile organik materyaller ile birlikte uygulanarak verim artışını arttırmaya yönelik çalışmalar yaygınlaşmaktadır.

Organik madde kaynağı olarak ülkemizde yoğun olarak tercih edilen ahır gübresinin pahalı olması ve kolay temin edilememesi kullanılmasını sınırlandırmaktadır. Azot ve potasyum içeriğinin ahır gübresine oranla daha zengin olduğu, toprağın fosfor içeriğini arttırmada önemli etkiye sahip bulunduğu bildirilen çay atığının bitkisel üretimde alternatif gübre olarak kullanımı birçok araştırmacı tarafından önerilmiștir (Kropsiz 1992; Samet 1996; Kacar 1997; Siddiqui ve ark. 2011). Atık mantar kompostunun toprağın biyolojik aktivitesini arttırması (Debosz ve ark. 2002; Vandenkoornhuyse ve ark. 2002), organik madde içeriğinin zengin olması, optimum düzeyde besin elementi içermesi, nötre yakın $\mathrm{Ph}$ s1 dolayısı ile bitkiler için kaliteli bir gübre olabileceği bildirilmiştir (Pill ve ark. 1993; Ahlawat ve ark. 2010; Ahlawat ve ark. 2011). Organik materyallerin, organik gübre ve mineral gübre kombinasyonunun besin dönüşümünü, toprak neminin korunmasını, katyon değişim kapasitesini arttırdığı, toprak fiziksel ve biyolojik özelliklerini iyileştirdiği ve erozyonun kontrolünü sağladığı bildirilmektedir (Akça ve Namlı 2015; Demir ve Gülser 2015; Özdemir ve ark. 2015; Gülser ve ark. 2015). Gelişmiş ülkelerde olduğu gibi ülkemizde de giderek artan bitkisel kökenli atıkların ve tarımsal sanayi atıklarının doğrudan ya da bazı ön işlemlerden geçirildikten sonra tarım topraklarında kullanılması çeşitli yönlerden yararlı olacaktır (Kütük ve ark. 1996).

$\mathrm{Bu}$ araştırmada çay atığı, atık mantar kompostu ve inorganik gübre uygulamalarının çemen (Trigonella Foenum Graecum) bitkisinin besin elementi içeriğine etkilerinin araştırılması amaçlanmıştır.

\section{Materyal ve Yöntem}

Araştırma Van Yüzüncü Y1l Üniversitesi, Ziraat Fakültesi Toprak Bilimi ve Bitki Besleme Bölümüne ait iklim odasında yürütülmüştür. Bitkiler, tohum çimlenme sürecinden itibaren büyüme ve gelişme süresince $\% 45-55$ nem, 16 saat aydınlık ve 8 saat karanlık fotoperiyod, $25 \pm 1^{\circ} \mathrm{C}$ sicaklık ile 10000 Lüx Gün ${ }^{-1} 1$ şı intensitesi olacak şekilde ayarlanan kontrollü koşullar altında yetiştirilmişlerdir. Deneme 3 tekrarlamalı olarak 54 saksıda faktöriyel deneme desenine göre planlanmıştır. Denemede $3 \mathrm{~kg}$ kapasiteli saksılara 15 adet Çemen bitkisi (Trigonella Foenum Graecum) tohumu ekilerek birinci haftanın sonunda 5 adet bitki kalacak şekilde seyreltme işlemi yapılmıştır. Denemede çay atığ $(\% 0, \% 2.5$ ve \%5.0) ve atık mantar kompostu $\left(\% 0, \% 5, \% 10\right.$ ton $\left.\mathrm{da}^{-1}\right)$ üç farkl1 dozda uygulanmıştır. İnorganik gübre olarak amonyum sülfat $(0,125$, $\left.250 \mathrm{mg} \mathrm{N} \mathrm{kg}^{-1}\right)$, triple süper fosfat $\left(0,50,100 \mathrm{mg} \mathrm{P}_{2} \mathrm{O}_{5} \mathrm{~kg}^{-1}\right)$ ve potasyum sülfatın $\left(0,75,150 \mathrm{mg} \mathrm{K}_{2} \mathrm{O} \mathrm{kg}^{-1}\right)$ üç farklı dozu kullanılmıştır. Başlangıcından sonuna kadar saf su kullanılan deneme 8 hafta sonra sonlandırılmış ve bitkiler kökleri ile birlikte bütün olarak çıkartılmıştır. Sırası ile çeşme suyu ve saf su ile yıkanan bitkiler, $70^{\circ} \mathrm{C}$ 'de sabit ağırlığa ulaşıncaya kadar etüvde kurutulduktan sonra ögütülerek analize hazır hale getirilmiştir. Bitki örneklerinde azot içeriği Kjehdal yöntemi ile, fosfor içeriği spektrofotometrik yöntemle, $\mathrm{K}, \mathrm{Ca}, \mathrm{Mg}, \mathrm{Fe}, \mathrm{Mn}$, $\mathrm{Zn}$ ve $\mathrm{Cu}$ içerikleri kuru yakma ile elde edilen ekstraktlarda atomik absorbsiyon spektrofotometre cihazı (Thermo ICE 3000 serisi) kullanılarak (Kacar ve İnal 2008) belirlenmiştir.

Deneme toprağının bazı fiziksel ve kimyasal özellikleri standart toprak analiz yöntemleri kullanılarak belirlenmiştir (Kacar 2009).

Elde edilen verilerin istatistiksel analizlerinde SPSS paket programından yararlanılmış ve elde edilen sonuçlar Duncan çoklu karşılaştırma testine göre gruplandırılmıştır (SPSS 2018).

Denemede kullanılan toprağın bazı fiziksel ve kimyasal özellikleri Çizelge 1'de verilmiştir. Deneme toprağ bünyeli, hafif alkali reaksiyonlu, tuzsuz, az kireçli, organik madde, fosfor ve çinko içeriği bakımından yetersiz, diğer besin elementleri bakımından yeterli düzeyde bulunmuştur.

Yetiştirme ortamında kullanılan çay atığı ve atık mantar kompostunun $\mathrm{pH}$ değerleri sırası ile hafif asit ve hafif alkali sınıfinda, belirlenmiştir. Bu organik materyallerin EC değerleri ise sırası ile $2.34 \mathrm{dS} \mathrm{m}^{-1}$ ve $4.24 \mathrm{dS} \mathrm{m}^{-1}$ olarak bulunmuştur. Kullanilan bu materyaller tuzluluk bakımindan değerlendirildiğinde, hafif tuzlu sınıfında bulunmaktadırlar. Araştırmada kullanılan çay atığının ve mantar kompostunun $\mathrm{C} / \mathrm{N}$ oranları sırası ile 15.46 ve 16.65 olarak belirlenmiştir. (Çizelge 2) $\mathrm{Bu} \mathrm{C} / \mathrm{N}$ oranları, materyallerin yetiştirme ortamlarında parçalanmalarının hızlı bir şekilde geliştiğini göstermiştir. Gülser ve Pekşen (2003), yetiştirme ortamlarında kullandıkları çay atığının $\mathrm{pH}, \mathrm{EC}$ ve $\mathrm{C} / \mathrm{N}$ oranlarını sırası ile $7.2, \% 0.90$ ve 22.95 olarak bildirmişlerdir. Pekşen ve Yakupoğlu (2009), yetiştirme ortamına ilave ettikleri çay atı̆̆ının $\mathrm{C} / \mathrm{N}$ oranını 24.18 olarak bulmuşlardır. Jordan ve ark. (2008), üzerinde çalıştıkları atık mantar kompostunun pH, EC ve $\mathrm{C} / \mathrm{N}$ oranını siras1 ile $6.0-7.9,6.8-15 \mathrm{mS} \mathrm{cm} \mathrm{cm}^{-1}, 14-24$ aralığında bildirmişlerdir.

Çizelge 1. Deneme toprağının bazı fiziksel ve kimyasal özellikleri.

Table 1. Some physical and chemical properties of experimental soil.

\begin{tabular}{ccccccccccccc}
\hline & & Kireç & OM & EC & P & K & Ca & Mg & Fe & Mn & $\mathrm{Zn}$ & $\mathrm{Cu}$ \\
$\mathrm{pH}$ & Tekstür & $\%$ & $\%$ & $\mathrm{dS} \mathrm{m}^{-1}$ & & & & & $\mathrm{mg} \mathrm{kg}^{-1}$ & & \\
\hline 7.81 & Tin & 3.86 & 1.32 & 0.36 & 5.50 & 298 & 3034 & 405 & 5.58 & 29.84 & 0.58 & 0.81 \\
\hline
\end{tabular}


Çizelge 1. Denemede kullanılan farklı organik materyallerin bazı fiziksel ve kimyasal özellikleri.

Table 2. Some physical and chemical properties of different organic materials used in the experiment.

\begin{tabular}{lcc}
\hline Parametre & Çay atı̆̆ & Atık mantar kompostu \\
\hline PH & 5.62 & 7.72 \\
EC $\left(\mathrm{dS} \mathrm{m}^{-1}\right)$ & 2.3 & 4.3 \\
Organik madde $(\%)$ & 94.59 & 70.04 \\
Organik karbon $(\%)$ & 54.87 & 40.63 \\
Azot (\%) & 3.55 & 2.44 \\
C/N & 15.46 & 16.65 \\
Nem $(\%)$ & 22.89 & 42.12 \\
\hline
\end{tabular}

\section{Bulgular ve Tartışma}

Farklı organik materyallerin ve inorganik gübre uygulamalarının bitki besin elementi içeriklerine etkileri istatistiksel anlamda önemli bulunmuştur. Farklı uygulamalarda elde edilen makro ve mikro bitki besin elementi içeriklerine ilişkin varyans analiz sonuçları çizelge 3 ve 4'de, Duncan harflendirmeleri Çizelge 5 ve 6 'da verilmiştir.

Çizelge 3 ve 4 incelendiğinde organik materyal çeşidinin bitkinin $\mathrm{N}, \mathrm{Ca}, \mathrm{Fe}$ ve $\mathrm{Zn}$ içeriğinde istatistiksel anlamda \%1 düzeyinde, $\mathrm{Mg}$ içeriğinde ise $\% 5$ düzeyinde önemli değişim meydana getirdiği belirlenmiştir. ÇA uygulamalarının N, P, Fe, $\mathrm{Mn}$ içerikleri üzerinde meydana getirdikleri değişim istatistiksel anlamda $\% 1$ düzeyinde önemli bulunmuştur. AMK uygulamaları ise $\mathrm{N}, \mathrm{P}, \mathrm{Mg}, \mathrm{Ca}, \mathrm{Fe}$ ve $\mathrm{Zn}$ içeriklerinde \%1 düzeyinde, $\mathrm{Mn}$ içeriğinde $\% 5$ düzeyinde etkili olmuşlardır. İG uygulamalarının $\mathrm{N}, \mathrm{P}, \mathrm{K}, \mathrm{Fe}, \mathrm{Zn}, \mathrm{Cu}$ içerikleri üzerine etkileri $\% 1$ düzeyinde önemli bulunmuştur. ÇAxİG ve AMKxİG interaksiyonları bitkinin $\mathrm{N}, \mathrm{P}$ ve $\mathrm{Zn}$ içerikleri üzerinde \%1 düzeyinde önemli değişim meydana getirmişlerdir. Bitkinin $\mathrm{Mg}$ ve Ca içerikleri AMKxİG interaksiyonlarından sırası ile \%5 ve $\% 1$ düzeyinde etkilenmişlerdir.
Çizelge 5 incelendiğinde, bitkilerin azot ve fosfor içeriklerinin artan çay atığı dozları ile birlikte istatistiksel anlamda önemli düzeyde artış gösterdiği belirlenmiştir. Çay atığı uygulamalarında $\mathrm{K}$ içeriğinde de istatistiksel anlamda önemli olmayan bir artış belirlenmiştir. En yüksek azot ve fosfor içerikleri sırası ile $\% 4.38$ ve $\% 0.31$ olarak ÇA2 uygulamasında en düşük azot ve fosfor içerikleri ise $\% 4.07$ ve \%0.27 olarak ÇA0 uygulamasında elde edilmiştir. Kacar (1997), çay atığının azot içeriğinin ahır gübresine oranla 3 kat daha zengin olduğunu ve potasyum içeriğinin de ahır gübresinden daha yüksek olduğunu bildirmiştir. Çay atıklarının $N$ içeriklerinin yüksek olduğu ve yetiştirme ortamında kullanılabilirliği değişik araştırmacılar (Gülser ve Pekşen 2003; Çolak ve ark. 2007; Pekşen ve Günay 2009) tarafindan bildirilmiştir. (Siddiqui ve ark. 2011), \%50 çay atığ1 $+\% 50$ inorganik gübre uygulamalarının Centella asiatica L. bitkisinin N, P, K alımını arttırdığını belirlemişlerdir. Aşık ve Kütük (2012), çim bitkilerinin N P K alımında, Kropsis (1992), sebzelerde $\mathrm{N}$ içeriğinde çay atığı uygulamaları ile artış belirlemişlerdir. Atık mantar kompostu uygulamalarında ise fosfor, magnezyum ve kalsiyum içeriklerinde artışlar meydana gelmiş ve bu artışlar önemli bulunmuştur. En yüksek fosfor, magnezyum ve kalsiyum içerikleri $\% 3.38, \% 1.22$ ve $\% 4.23$ olarak AMK2 uygulamalarında elde edilirken en düşük P, Mg ve $\mathrm{Ca}$ içerikleri $\% 0.25, \% 1.01$ ve $\% 3.24$ olarak AMK0 uygulamasında elde edilmiştir. Golı ve ark. (2015), atık mantar kompostu uygulamalarının marulda vejetatif büyümeyi ve $\mathrm{N}, \mathrm{P}$, $\mathrm{K}$ ve $\mathrm{Ca}$ içeriğini kontrole kıyasla \%30 oranında arttırdığını bildirmişlerdir. Demirtaş ve ark. (2000), örtü altı yetiştiriciliğinde domates bitkisinde atık mantar kompostu uygulamaları ile yaprak $\mathrm{K}$ içeriğinin arttığını belirlemişlerdir. (Soechtig ve Grabbe 1995), atık mantar kompostu uygulama dozunun belirlenmesinde tuz içeriğinin sınırlandırıcı bir faktör olduğunu bildirmiştir ve tuz içeriğinin önemini vurgulamıştır. Erkel (1990), atık mantar kompostunun 1-1.5 y1l aç1kta bekletilmesi ve sonrasinda 5-6 defa yıkanması durumunda kullanılmasının uygun olduğu bildirilmiştir.

Çizelge 3. Farklı uygulamaların makro besin elementi içeriklerine etkisine ilişkin varyans analiz sonuçları.

Table 3. The Variance analysis results belong effects of different applications on macro nutrient contents.

\begin{tabular}{|c|c|c|c|c|c|c|c|c|c|c|c|}
\hline \multirow{2}{*}{ VK } & \multirow{2}{*}{ SD } & \multicolumn{2}{|r|}{$\mathrm{N}$} & \multicolumn{2}{|r|}{$\mathrm{P}$} & \multicolumn{2}{|c|}{ K } & \multicolumn{2}{|c|}{$\mathrm{Mg}$} & \multicolumn{2}{|c|}{$\mathrm{Ca}$} \\
\hline & & KO & $\mathrm{F}$ & $\mathrm{KO}$ & $\mathrm{F}$ & $\mathrm{KO}$ & $F$ & $\mathrm{KO}$ & $\mathrm{F}$ & $\mathrm{KO}$ & $\mathrm{F}$ \\
\hline OMÇ & 1 & 1.28 & $15345.80 * *$ & 2.96 & $0.04^{\text {odd }}$ & 0.018 & $0.17^{\text {öd }}$ & 0.064 & $4.45^{*}$ & 2.91 & $9.93 * *$ \\
\hline ÇA & 2 & 0.38 & $3797.48^{* *}$ & 0.005 & $10.41 * *$ & 0.60 & $0.44^{\text {öd }}$ & 0.06 & 3.07 öd & 1.20 & $2.47^{\text {öd }}$ \\
\hline AMK & 2 & 0.56 & $8387.56^{* *}$ & 0.020 & $22.213^{* *}$ & 0.148 & $1.88^{\text {öd }}$ & 0.103 & $10.90^{* *}$ & 2.32 & $22.18^{* *}$ \\
\hline İG & 2 & 0.26 & $3148.36^{* *}$ & 0.021 & $31.14 * *$ & 3.03 & $28.31^{* *}$ & 0.010 & $0.73^{\text {od }}$ & 0.67 & 2.28 öd \\
\hline ÇAXİG & 4 & 0.348 & $3481.26^{* *}$ & 0.04 & $9.208 * *$ & 0.17 & 1.27 öd & 0.002 & 0.11 öd & 0.28 & 0.59 öd \\
\hline AMKXİG & 4 & 0.450 & $6749.39 * *$ & 0.005 & $5.50^{* * *}$ & 0.08 & $1.008^{\mathrm{od}}$ & 0.041 & $4.33^{*}$ & 1.80 & $17.206^{* *}$ \\
\hline
\end{tabular}

** ile gösterilen F değeri \%1 düzeyinde önemlidir. * ile gösterilen F değeri \%5 düzeyinde önemlidir. ÇA: Çay atı̆̆ı, AMK: Atık Mantar Kompostu, İG: inorganik gübre.

Çizelge 4. Farklı uygulamaların mikro besin elementi içeriklerine etkisine ilişkin varyans analiz sonuçları.

Table 4. The Variance analysis results belong effects of different applications on micro nutrient contents.

\begin{tabular}{|c|c|c|c|c|c|c|c|c|c|}
\hline \multirow{2}{*}{ VK } & \multirow{2}{*}{ SD } & \multicolumn{2}{|c|}{$\mathrm{Fe}$} & \multicolumn{2}{|c|}{$\mathrm{Zn}$} & \multicolumn{2}{|c|}{$\mathrm{Cu}$} & \multicolumn{2}{|c|}{$\mathrm{Mn}$} \\
\hline & & $\mathrm{KO}$ & $\mathrm{F}$ & $\mathrm{KO}$ & $\mathrm{F}$ & $\mathrm{KO}$ & $\mathrm{F}$ & $\mathrm{KO}$ & $\mathrm{F}$ \\
\hline OMÇ & 1 & 83871.58 & $13.38 * *$ & 13202.04 & $652.87 * *$ & 2.81 & $0.29^{\text {öd }}$ & 249.75 & $0.59^{\text {öd }}$ \\
\hline ÇA & 2 & 23107.05 & $8.08 * *$ & 4.6 & $0.4^{\mathrm{öd}}$ & 9.16 & $0.99^{\text {öd }}$ & 11514.98 & $41.74 * *$ \\
\hline AMK & 2 & 196985.84 & $20.35^{* *}$ & 1366.604 & $47.64 * *$ & 10.84 & $1.06^{\text {öd }}$ & 3261.18 & $5.73^{*}$ \\
\hline İG & 2 & 354577.10 & $5.66^{* *}$ & 2233.26 & $110.44 * *$ & 64.49 & $6.64 * *$ & 1260.80 & $2.98^{\mathrm{öd}}$ \\
\hline ÇAXİG & 4 & 2143.70 & $0.75^{\mathrm{od}}$ & 154.8 & $13.16^{* *}$ & 28.04 & $3.03^{\text {öd }}$ & 2983.44 & $10.82^{\text {öd }}$ \\
\hline AMKXİG & 4 & 5527.67 & $0.57^{\mathrm{od}}$ & 1972.13 & $68.75^{* *}$ & 15.29 & 1.5 öd & 455.89 & $0.80^{\text {öd }}$ \\
\hline
\end{tabular}


Çizelge 5. Farklı organik materyallerin ve inorganik gübrelerin makro besin element içeriklerine etkisi.

Table 5. Effect of different organic materials and inorganic fertilizers on macro nutrient element contents.

\begin{tabular}{|c|c|c|c|c|c|c|c|}
\hline \multirow{2}{*}{$\begin{array}{l}\text { Makro besin } \\
\text { elementleri }\end{array}$} & \multirow{2}{*}{ Org. materyal } & \multirow{2}{*}{$\operatorname{Doz}(\%)$} & \multicolumn{3}{|c|}{ İnorganik gübre } & \multirow[b]{2}{*}{ Ortalama } & \multirow[b]{2}{*}{ Genel ort. } \\
\hline & & & İG0 & İG1 & İG2 & & \\
\hline \multirow{8}{*}{$\mathrm{N}(\%)$} & \multirow{4}{*}{$\begin{array}{l}\text { Çay } \\
\text { atığ } 1\end{array}$} & ÇA0(0) & $3.24 \mathrm{~h}$ & $4.46 \mathrm{de}$ & $4.53 \mathrm{~b}$ & $4.07 \mathrm{C}$ & \multirow{4}{*}{$4.31 \mathrm{~B}$} \\
\hline & & ÇA1(2.5) & $4.30 \mathrm{f}$ & $4.48 \mathrm{c}$ & $4.61 \mathrm{a}$ & $4.47 \mathrm{~A}$ & \\
\hline & & ÇA2(5) & $4.22 \mathrm{f}$ & $4.44 \mathrm{e}$ & $4.47 \mathrm{~cd}$ & $4.38 \mathrm{~B}$ & \\
\hline & & Ortalama & $3.92 \mathrm{C}$ & $4.46 \mathrm{~B}$ & $4.54 \mathrm{~A}$ & & \\
\hline & \multirow{4}{*}{$\begin{array}{l}\text { Atık mantar } \\
\text { kompostu }\end{array}$} & AMK0(0) & $5.43 a$ & $4.35 \mathrm{~g}$ & $4.52 \mathrm{e}$ & $4.77 \mathrm{~A}$ & \multirow{4}{*}{$4.61 \mathrm{~A}$} \\
\hline & & $\operatorname{AMK1(2.5)}$ & $4.63 \mathrm{~d}$ & $4.76 \mathrm{c}$ & $4.83 \mathrm{~b}$ & $4.74 \mathrm{~B}$ & \\
\hline & & AMK2(5) & $4.47 \mathrm{f}$ & $3.87 \mathrm{~h}$ & $4.62 \mathrm{~d}$ & $4.32 \mathrm{C}$ & \\
\hline & & Ortalama & $4.85 \mathrm{~A}$ & $4.67 \mathrm{~B}$ & $4.33 \mathrm{C}$ & & \\
\hline \multirow{8}{*}{$\mathrm{P}(\%)$} & \multirow{4}{*}{$\begin{array}{l}\text { Çay } \\
\text { atığ }\end{array}$} & ÇA0(0) & $0.26 \mathrm{~cd}$ & $0.26 \mathrm{~cd}$ & $0.28 \mathrm{c}$ & $0.27 \mathrm{~B}$ & \multirow{4}{*}{0.286} \\
\hline & & ÇA1(2.5) & $0.26 \mathrm{~cd}$ & $0.28 \mathrm{bc}$ & $0.30 \mathrm{bc}$ & $0.28 \mathrm{~B}$ & \\
\hline & & ÇA2(5) & $0.23 \mathrm{~d}$ & $0.31 \mathrm{~b}$ & $0.38 \mathrm{a}$ & $0.31 \mathrm{~A}$ & \\
\hline & & Ortalama & $0.25 \mathrm{C}$ & $0.28 \mathrm{~B}$ & $0.32 \mathrm{~A}$ & & \\
\hline & \multirow{4}{*}{$\begin{array}{l}\text { Atık mantar } \\
\text { kompostu }\end{array}$} & $\mathrm{AMK} 0(0)$ & $0.25 \mathrm{c}$ & $0.25 \mathrm{c}$ & $0.26 \mathrm{c}$ & $0.25 \mathrm{~B}$ & \multirow{4}{*}{0.288} \\
\hline & & $\operatorname{AMK1}(2.5)$ & $0.25 \mathrm{c}$ & $0.27 \mathrm{c}$ & $0.29 b c$ & $0.27 \mathrm{~B}$ & \\
\hline & & AMK2(5) & $0.27 \mathrm{c}$ & $0.33 b$ & $0.43 \mathrm{a}$ & $0.34 \mathrm{~A}$ & \\
\hline & & Ortalama & $0.26 \mathrm{~B}$ & $0.28 \mathrm{~B}$ & $0.32 \mathrm{~A}$ & & \\
\hline \multirow{8}{*}{$\mathrm{K}(\%)$} & \multirow{4}{*}{$\begin{array}{l}\text { Çay } \\
\text { atığ } 1\end{array}$} & ÇA0(0) & $3.86 \mathrm{a}$ & 3.24abcd & $2.58 \mathrm{~d}$ & 3.22 & \multirow{4}{*}{3.28} \\
\hline & & ÇA1(2.5) & $3.46 \mathrm{ab}$ & $3.53 \mathrm{ab}$ & $2.74 \mathrm{~cd}$ & 3.24 & \\
\hline & & ÇA2(5) & $3.68 \mathrm{ab}$ & $3.34 \mathrm{abc}$ & $3.11 \mathrm{bcd}$ & 3.38 & \\
\hline & & Ortalama & $3.67 \mathrm{~A}$ & $3,37 \mathrm{~A}$ & $2.81 \mathrm{~B}$ & & \\
\hline & \multirow{4}{*}{$\begin{array}{l}\text { Atık mantar } \\
\text { kompostu }\end{array}$} & $\mathrm{AMK} 0(0)$ & $3.80 \mathrm{a}$ & $3.18 \mathrm{bcd}$ & $2.74 d$ & 3.24 & \multirow{4}{*}{3.25} \\
\hline & & $\operatorname{AMK1}(2.5)$ & $3.40 \mathrm{abc}$ & $3.29 \mathrm{abc}$ & $2.69 \mathrm{~d}$ & 3.12 & \\
\hline & & AMK2(5) & $3.62 \mathrm{ab}$ & $3.44 \mathrm{abc}$ & $3.08 \mathrm{~cd}$ & 3.38 & \\
\hline & & Ortalama & $3.60 \mathrm{~A}$ & $3.30 \mathrm{~B}$ & $2.83 \mathrm{C}$ & & \\
\hline \multirow{8}{*}{$\operatorname{Mg}(\%)$} & \multirow{4}{*}{$\begin{array}{l}\text { Çay } \\
\text { atığ }\end{array}$} & ÇA0(0) & $1.09 \mathrm{ab}$ & $1.10 \mathrm{ab}$ & $1.17 \mathrm{a}$ & $1.12 \mathrm{~A}$ & \multirow{4}{*}{$1.028 \mathrm{~B}$} \\
\hline & & ÇA1(2.5) & $0.88 \mathrm{~b}$ & $0.98 \mathrm{ab}$ & $1.03 \mathrm{ab}$ & $0.96 \mathrm{~B}$ & \\
\hline & & ÇA2(5) & $0.93 \mathrm{ab}$ & $1.03 \mathrm{ab}$ & $1.05 \mathrm{ab}$ & $1.12 \mathrm{AB}$ & \\
\hline & & Ortalama & 0.97 & 1.04 & 1.08 & & \\
\hline & & $\mathrm{AMK} 0(0)$ & $0.97 \mathrm{~b}$ & $0.99 \mathrm{~b}$ & $1.10 \mathrm{~b}$ & $1.01 \mathrm{~B}$ & \\
\hline & Atık mantar & $\operatorname{AMK1}(2.5)$ & $0.99 b$ & $1.10 \mathrm{~b}$ & $1.06 \mathrm{~b}$ & $1.05 \mathrm{~B}$ & \\
\hline & kompostu & AMK2(5) & $1.38 \mathrm{a}$ & $1.16 \mathrm{~b}$ & $1.12 \mathrm{~b}$ & $1.22 \mathrm{~A}$ & $1.097 \mathrm{~A}$ \\
\hline & & Ortalama & 1.11 & 1.09 & 1.09 & & \\
\hline & & ÇA0(0) & $3.50 \mathrm{ab}$ & $3.13 \mathrm{ab}$ & $4.25 \mathrm{a}$ & 3.62 & \\
\hline & Çay & ÇA1(2.5) & $2.46 \mathrm{~b}$ & $3.21 \mathrm{ab}$ & $3.50 \mathrm{ab}$ & 3.05 & \\
\hline & atığ & ÇA2(5) & $2.57 \mathrm{~b}$ & $2.94 \mathrm{ab}$ & $3.31 \mathrm{ab}$ & 2.95 & $3.208 \mathrm{~B}$ \\
\hline & & Ortalama & $2.85 \mathrm{~B}$ & $3.10 \mathrm{AB}$ & $3.67 \mathrm{~A}$ & & \\
\hline $\mathrm{Ca}(\%)$ & & AMK0(0) & $2.80 \mathrm{c}$ & $3.31 b c$ & $3.62 \mathrm{~b}$ & $3.24 \mathrm{~B}$ & \\
\hline & Atık mantar & $\operatorname{AMK1(2.5)}$ & $3.43 b$ & $3.63 b$ & $3.57 \mathrm{~b}$ & $3.54 \mathrm{~B}$ & 36724 \\
\hline & kompostu & AMK2(5) & $5.46 \mathrm{a}$ & $3.54 \mathrm{~b}$ & $3.70 \mathrm{~b}$ & $4.23 \mathrm{~A}$ & $3.0 / 3 \mathrm{~A}$ \\
\hline & & Ortalama & $3.90 \mathrm{~A}$ & $3.63 \mathrm{AB}$ & $3.50 \mathrm{~B}$ & & \\
\hline
\end{tabular}

a, b, c, : farklı harflerle gösterilen ortalamalar arasındaki fark kendi satırında ve kendi sütununda önemlidir. İG1: $\mathrm{N}_{1} 125 ; \mathrm{P}_{2} \mathrm{O}_{5}, 50 ; \mathrm{K}_{2} \mathrm{O}, 75\left(\mathrm{mg} \mathrm{kg}^{-1}\right)$, İG2: $\mathrm{N}_{2} 250 ; \mathrm{P}_{2} \mathrm{O}$, $100 ; \mathrm{K}_{2} \mathrm{O}, 150\left(\mathrm{mg} \mathrm{kg}^{-1}\right)$.

Çay atı̆̆ı ile birlikte, artan dozlarda inorganik gübre uygulamalarının bitkilerin azot, fosfor ve magnezyum içeriklerini arttırdı ̆̆ 1 belirlenmiştir. Atık mantar kompostu uygulamaları ile birlikte artan inorganik gübre dozları ise fosfor dışında diğer makro besin elementleri içeriğinde azalma meydana getirmiştir. $\mathrm{Bu}$ araştırmada bitkilerin $\mathrm{N}, \mathrm{Mg}$ ve $\mathrm{Ca}$ içerikleri organik materyalin çeşidine bağlı olarak önemli düzeyde değişim göstermiştir. Atık mantar kompostu uygulamalarında sirası ile $\% 4.61, \% 1.10$ ve $\% 3.67$ olarak elde edilen makro besin elementi içerikleri ÇA uygulamalarında siras1 ile $\% 4.31, \% 1.03$ ve $\% 3.21$ olarak elde edilen değerlerden istatistiksel anlamda farklı ve yüksek bulunmuştur. Mehta ve ark. (2010), çemen bitkisinde $20 \mathrm{~kg} \mathrm{~N} \mathrm{ha}^{-1}$ ve $40 \mathrm{~kg} \mathrm{P}_{2} \mathrm{O}_{5} \mathrm{ha}^{-1}$ uygulamaları ile bitkinin azot ve potasyum içeriğinde artış meydana geldiğini bildirmişlerdir.

Farklı uygulamaların bitkilerin mikro besin elementi içeriğine etkileri incelendiğinde, artan ÇA dozları ile birlikte bitkilerin mangan dışında mikro besin elementleri içeriklerinde azalma belirlenirken mangan içeriğinde ise önemli düzeyde artış elde edilmiştir. En yüksek Fe içeriği $381.99 \mathrm{mg} \mathrm{kg}^{-1}$ olarak ÇA0 uygulamasında elde edilmiştir $\mathrm{Zn}$ ve $\mathrm{Cu}$ içeriklerindeki 
Çizelge 6. Farklı organik materyallerin ve inorganik gübrelerin mikro besin elementi içeriklerine etkisi.

Table 6. Effect of different organic materials and inorganic fertilizers on micro nutrient element contents.

\begin{tabular}{|c|c|c|c|c|c|c|c|}
\hline \multirow{2}{*}{$\begin{array}{l}\text { Mikro besin } \\
\text { elementleri }\end{array}$} & \multirow{2}{*}{ Org. materyal } & \multirow{2}{*}{ Doz } & \multicolumn{3}{|c|}{ İnorganik gübre } & \multirow[b]{2}{*}{ Ortalama } & \multirow[b]{2}{*}{ Genel ort } \\
\hline & & & İG0 & İG1 & İG2 & & \\
\hline \multirow{8}{*}{$\begin{array}{c}\mathrm{Fe} \\
\left(\mathrm{mg} \mathrm{kg}^{-1}\right)\end{array}$} & \multirow{4}{*}{$\begin{array}{l}\text { Çay } \\
\text { atığ1 }\end{array}$} & ÇA0(0) & $433.97 \mathrm{a}$ & $336.6 \mathrm{ab}$ & $345.3 \mathrm{ab}$ & $381.99 \mathrm{~A}$ & \multirow{4}{*}{$325.62 \mathrm{~B}$} \\
\hline & & ÇA1(2.5) & $331.3 b c$ & $279.8 b c$ & $240.42 \mathrm{c}$ & $311.05 \mathrm{~B}$ & \\
\hline & & ÇA2(5) & $312.9 \mathrm{bc}$ & $306.4 b c$ & $313.8 b c$ & \multirow[t]{2}{*}{$283.85 \mathrm{~B}$} & \\
\hline & & Ortalama & $359.40 \mathrm{~A}$ & $317.6 \mathrm{AB}$ & 299.88B & & \\
\hline & \multirow{4}{*}{$\begin{array}{c}\text { Mantar } \\
\text { kompostu }\end{array}$} & $\mathrm{AMK} 0(0)$ & $642.90 \mathrm{a}$ & $613.02 \mathrm{a}$ & $469.2 \mathrm{ab}$ & $575.03 \mathrm{~A}$ & \multirow{4}{*}{ 404.44A } \\
\hline & & AMK1(2.5) & $371.9 \mathrm{bc}$ & $278.62 \mathrm{c}$ & $283.2 b c$ & $327.03 \mathrm{~B}$ & \\
\hline & & AMK2(5) & $353.1 \mathrm{bc}$ & $365.3 \mathrm{bc}$ & $262.65 c$ & $311.26 \mathrm{~B}$ & \\
\hline & & Ortalama & $455.99 \mathrm{~A}$ & $418.9 \mathrm{AB}$ & $338.35 \mathrm{~B}$ & & \\
\hline \multirow{8}{*}{$\begin{array}{c}\mathrm{Zn} \\
\left(\mathrm{mg} \mathrm{kg}^{-1}\right)\end{array}$} & \multirow{4}{*}{$\begin{array}{l}\text { Çay } \\
\text { atığ } 1\end{array}$} & ÇA0(0) & $17.02 \mathrm{~d}$ & $32.31 \mathrm{a}$ & $18.16 \mathrm{~cd}$ & 22.50 & \multirow{4}{*}{$22.17 \mathrm{~B}$} \\
\hline & & ÇA1(2.5) & $29.43 \mathrm{ab}$ & $20.62 \mathrm{~cd}$ & $17.90 \mathrm{~cd}$ & 22.65 & \\
\hline & & ÇA2(5) & $23.93 b c$ & $17.71 \mathrm{~cd}$ & $22.40 \mathrm{~cd}$ & \multirow[t]{2}{*}{21.34} & \\
\hline & & Ortalama & $23.46 \mathrm{~A}$ & $23.55 \mathrm{~A}$ & $19.48 \mathrm{~B}$ & & \\
\hline & \multirow{4}{*}{$\begin{array}{c}\text { Mantar } \\
\text { kompostu }\end{array}$} & $\mathrm{AMK} 0(0)$ & $20.72 \mathrm{f}$ & $95.31 \mathrm{a}$ & $19.16 \mathrm{f}$ & $45.06 \mathrm{~B}$ & \multirow{4}{*}{$53.44 \mathrm{~A}$} \\
\hline & & $\mathrm{AMK} 1(2.5)$ & $64.59 \mathrm{c}$ & 43.79de & $34.63 \mathrm{e}$ & $47.67 \mathrm{~B}$ & \\
\hline & & AMK2(5) & $78.49 \mathrm{~b}$ & $79.91 b$ & $44.36 \mathrm{~d}$ & $67.58 \mathrm{~A}$ & \\
\hline & & Ortalama & $54.60 \mathrm{~B}$ & $73.00 \mathrm{~A}$ & $32.71 \mathrm{C}$ & & \\
\hline \multirow{8}{*}{$\begin{array}{c}\mathrm{Cu} \\
\left(\mathrm{mg} \mathrm{kg}^{-1}\right)\end{array}$} & \multirow{4}{*}{$\begin{array}{l}\text { Çay } \\
\text { atığ }\end{array}$} & ÇA0(0) & $13.66 \mathrm{abc}$ & $8.70 \mathrm{~cd}$ & $14.88 \mathrm{ab}$ & 12.41 & \multirow{4}{*}{11.32} \\
\hline & & ÇA1(2.5) & $12.68 \mathrm{abc}$ & $10.0 \mathrm{bcd}$ & $8.54 \mathrm{~cd}$ & 10.42 & \\
\hline & & ÇA2(5) & $16.83 a$ & $4.94 \mathrm{~d}$ & $11.57 \mathrm{abc}$ & \multirow[t]{2}{*}{11.11} & \\
\hline & & Ortalama & $14.39 \mathrm{~A}$ & $7.90 \mathrm{~B}$ & $11.66 \mathrm{~A}$ & & \\
\hline & \multirow{4}{*}{$\begin{array}{c}\text { Mantar } \\
\text { kompostu }\end{array}$} & AMK0(0) & $11.60 \mathrm{ab}$ & $10.91 \mathrm{ab}$ & $12.45 \mathrm{ab}$ & 11.65 & \multirow{4}{*}{11.78} \\
\hline & & AMK1(2.5) & $12.47 \mathrm{ab}$ & $10.50 \mathrm{ab}$ & $15.81 \mathrm{a}$ & 12.92 & \\
\hline & & AMK2(5) & $11.92 \mathrm{ab}$ & $11.75 \mathrm{ab}$ & $8.55 \mathrm{~b}$ & 10.74 & \\
\hline & & Ortalama & 12.00 & 11.05 & 12.27 & & \\
\hline \multirow{8}{*}{$\begin{array}{c}\mathrm{Mn} \\
\left(\mathrm{mg} \mathrm{kg}^{-1}\right)\end{array}$} & \multirow{4}{*}{$\begin{array}{l}\text { Çay } \\
\text { atığ1 }\end{array}$} & ÇA0(0) & $89.92 d$ & $99.50 \mathrm{~d}$ & $46.90 \mathrm{e}$ & $78.77 \mathrm{C}$ & \multirow{4}{*}{109.72} \\
\hline & & ÇA1(2.5) & $55.25 \mathrm{e}$ & $113.9 \mathrm{~cd}$ & $135.4 b c$ & 101.51B & \\
\hline & & ÇA2(5) & $120.2 \mathrm{~cd}$ & $174.1 \mathrm{a}$ & $152.4 \mathrm{ab}$ & $148.88 \mathrm{~A}$ & \\
\hline & & Ortalama & $88.46 \mathrm{C}$ & $129.16 \mathrm{~A}$ & $111.55 \mathrm{~B}$ & & \\
\hline & \multirow{4}{*}{$\begin{array}{c}\text { Mantar } \\
\text { kompostu }\end{array}$} & $\mathrm{AMK} 0(0)$ & $86.62 b$ & $90.58 b$ & $94.16 \mathrm{ab}$ & $90.46 \mathrm{~B}$ & \\
\hline & & AMK1(2.5) & $104.7 \mathrm{ab}$ & $106.9 \mathrm{ab}$ & $86.00 \mathrm{~b}$ & $98.96 \mathrm{~B}$ & 10542 \\
\hline & & AMK2(5) & $137.69 \mathrm{a}$ & $110.6 \mathrm{ab}$ & $132.3 \mathrm{ab}$ & $126.85 \mathrm{~A}$ & 105.42 \\
\hline & & Ortalama & 109.67 & 102.44 & 104.15 & & \\
\hline
\end{tabular}

a, b, c, : farklı harflerle gösterilen ortalamalar arasındaki fark kendi satırında ve kendi sütununda önemlidir. İG1: $\mathrm{N}_{,} 125 ; \mathrm{P}_{2} \mathrm{O}_{5}, 50 ; \mathrm{K}_{2} \mathrm{O}, 75$ (mg kg-1 $)$ İG2: $\mathrm{N}, 250 ; \mathrm{P}_{2} \mathrm{O}_{5}$, $100 ; \mathrm{K}_{2} \mathrm{O}, 150\left(\mathrm{mg} \mathrm{kg}^{-1}\right)$.

azalmalar ise istatistiksel anlamda önemli bulunmamıştır. Çay atığ1 uygulamalarında en yüksek ve en düşük Mn içerikleri $148.88 \mathrm{mg} \mathrm{kg}^{-1}$ ve $78.77 \mathrm{mg} \mathrm{kg}^{-1}$ olarak sırası ile ÇA2 ve ÇA0 dozlarında elde edilmişlerdir. Artan AMK dozları ile $\mathrm{Fe}$ ve $\mathrm{Cu}$ içeriklerinde azalmalar, $\mathrm{Zn}$ ve $\mathrm{Mn}$ içeriklerinde ise artışlar belirlenmiştir. $\mathrm{Bu}$ değişikler $\mathrm{Cu}$ içeriği dışında önemli bulunmuştur. Atık mantar kompostu uygulamalarında en yüksek ve en düşük Fe içerikleri $575.03 \mathrm{mg} \mathrm{kg}^{-1}$ ve $311.26 \mathrm{mg} \mathrm{kg}^{-1}$ olarak siras1 ile AMK0 ve AMK2 uygulamalarında elde edilmişlerdir. En yüksek $\mathrm{Zn}$ ve $\mathrm{Mn}$ içerikleri ise $67.58 \mathrm{mg} \mathrm{kg}^{-1}$ ve $126.85 \mathrm{mg} \mathrm{kg}^{-1}$ olarak AMK2 uygulamalarında elde edilirken, en düşük $\mathrm{Zn}$ ve $\mathrm{Mn}$ içerikleri $45.06 \mathrm{mg} \mathrm{kg-1}$ ve 90.46 $\mathrm{mg} \mathrm{kg}{ }^{-1}$ olarak AMK0 uygulamalarında elde edilmişlerdir. Artan inorganik gübre dozları ile bitkilerin $\mathrm{Fe}, \mathrm{Zn}$ içeriklerinde her iki organik materyal uygulamasında da azalmalar, Mn içeriğinde ise artış belirlenmiştir. Bu değişiklikler istatistiksel olarak önemli bulunmuştur. Genel olarak AMK uygulamalarında elde edilen $\mathrm{Fe}$ ve $\mathrm{Zn}$ içerikleri ÇA uygulamalarında elde edilenlerden önemli düzeyde yüksek bulunmuştur. Çay atığı uygulamalarında elde edilen $\mathrm{Fe}$ ve $\mathrm{Zn}$ içerikleri sırası ile $325.62 \mathrm{mg} \mathrm{kg}^{-1}$ ve $22.17 \mathrm{mg} \mathrm{kg}^{-1}$ iken, atık mantar kompostu uygulamalarında Fe mg kg-1 ve $\mathrm{Zn} \mathrm{mg} \mathrm{kg}{ }^{-1}$ içerikleri 404.44 ve 53.44 olarak bulunmuşlardır. Atık mantar kompostunun yüksek düzeyde organik madde ve bitki besin elementi içermesi, $\mathrm{pH}$ düzeyinin nötre yakın olması ve yararlı mikroorganizmalar bulundurması, toprağın fiziksel ve kimyasal özelliklerine olumlu etkileri dolayısı ile bitkilerin besin elementi alımına olumlu etkilerinin olduğu bildirilmiş (Roy ve ark. 2015). Benzer şekilde Birben ve ark. (1999), atık mantar kompostunun yüksek miktarda amonyum ve suda çözünebilir 
tuz içermesi nedeni ile kullanılmasından önce bekletilmesi ve yıkama işlemine maruz bırakılması gerektiğini belirtmişlerdir. Guo ve Chorover (2006), atık mantar kompostunun kullanımını sınırlandıran en önemli faktörün yüksek oranda çözünebilir tuz içermesi olduğunu bildirmişlerdir. Parades ve ark. (2016), marul bitkisinde atık mantar kompostu uygulamalarının $\mathrm{K}, \mathrm{Fe}$ ve $\mathrm{Zn}$ içerikleri dışında diğer bitki besin elementlerinde artış meydana getirdiğini bildirmişlerdir.

$\mathrm{Bu}$ araştırmada elde edilen sonuçlar, aşağıda sunulmuş olan benzer konudaki araştırmaların sonuçları ile uyum sağlamaktadır.

Çay atıklarının $\mathrm{N}$ içeriklerinin yüksek olduğu ve yetiştirme ortamında kullanılabilirliği değişik araştırmacılar (Gülser ve Pekşen 2003; Çolak ve ark. 2007; Pekşen ve Günay, 2009). tarafindan bildirilmiştir. Siddiqui ve ark. (2011), \%50 çay atığ 1 $+\% 50$ inorganik gübre uygulamalarının Centella asiatica $\mathrm{L}$. bitkisinin $\mathrm{N}, \mathrm{P}, \mathrm{K}$ alımını arttırdığını belirlemişlerdir. Aşık ve Kütük (2012), çim bitkilerinin N P K alımında, Kropsis (1992), sebzelerde $\mathrm{N}$ içeriğinde çay atığı uygulamaları ile artış belirlemişlerdir. Golı ve ark. (2015), atık mantar kompostu uygulamalarının marulda vejetatif büyümeyi ve $\mathrm{N}, \mathrm{P}, \mathrm{K}$ ve $\mathrm{Ca}$ içeriğini kontrole kıyasla \%30 oranında arttırdığını bildirmişlerdir. Demirtaş ve ark. (2000), örtü altı yetiştiriciliğinde domates bitkisinde atık mantar kompostu uygulamaları ile yaprak $\mathrm{K}$ içeriğinin arttığını belirlemişlerdir. Parades ve ark. (2016), marul bitkisinde atık mantar kompostu uygulamalarının $\mathrm{K}, \mathrm{Fe}$ ve $\mathrm{Zn}$ içerikleri dışında diğer bitki besin elementlerinde artış meydana getirdiğini bildirmişlerdir.

\section{Sonuç}

$\mathrm{Bu}$ araştırmada atık mantar kompostu uygulamalarında elde edilen çemen bitkisinin $\mathrm{N}, \mathrm{Mg}, \mathrm{Ca}, \mathrm{Fe}$ ve $\mathrm{Zn}$ içerikleri çay atığ 1 uygulamalarında elde edilenlere kıyasla daha yüksek bulunmuştur. Ayrıca kimyasal gübrelerin atık mantar kompostu ve çay atığı ile birlikte uygulanmaları durumunda genel olarak bitki besin elementi içeriğinde artış meydana geldiği belirlenmiştir. En yüksek N içeriği AMK1İG2 uygulamasında, en yüksek $\mathrm{P}$ ve $\mathrm{K}$ içerikleri ise AMK2İG2 uygulamasında elde edilmişler ve Duncan çoklu karşılaştırma testine göre ÇA2İG2 uygulamasında elde edilen $\mathrm{P}$ ve $\mathrm{K}$ içerikleri ile aynı grupta yer almışlardır. Guo ve Chorover (2006), atık mantar kompostunun kullanımını sınırlandıran en önemli faktörün yüksek oranda çözünebilir tuz içermesi olduğunu bildirmişlerdir. Soechtig ve grabbe (1995), atık mantar kompostu uygulama dozunun belirlenmesinde tuz içeriğinin sınırlandırıcı bir faktör olduğunu bildirmiştir ve tuz içeriğinin önemini vurgulamıştır. Erkel (1990), tarafından atık mantar kompostunun 1-1.5 yıl açıkta bekletilmesi ve sonrasında 5-6 defa yıkanması durumunda kullanılmasının uygun olduğu bildirilmiş̧ir.

Elde edilen bulgular, çay atığı ve atık mantar kompostunun tıbbi bitkiler içerisinde önemli bir yere sahip olan çemen bitkisinin yetiştiriciliğinde olumlu etkiye sahip olduğu ve çiftlik gübresi ile inorganik gübrelerin kullanım miktarının azaltılmasına olanak sağlayacağını destekler niteliktedir. Ancak atık mantar kompostunun tuz içeriğinin uygulanmadan önce belirlenmesi ve yıkama işlemine maruz bırakılması önerilmektedir.

\section{Teşekkür}

Bu çalışma, FYL-2017-6289 no'lu proje kapsamında Van Yüzüncü Y1l Üniversitesi Bilimsel Araştırma Projeleri Başkanlığı tarafindan desteklenmiştir.

\section{Kaynaklar}

Abdelgani ME, Elsheikh EAE, Mukhtar NO (1998) The effect of rhizobium inoculation and chemical fertilization on seed quality of fenugreek. Food Chemistry 64: 289-293.

Ahlawat OP, Gupta P, Kumar S, Sharma DK (2010) Bioremediation of fungicides by spent mushroom substrate and its associated microflora. Indian J. Microbiology 50(4): 390-395.

Ahlawat OP, Manikandan K, Sagar MP, Rai D, Vijai B (2011) Effect of composted button mushroom spent substrate on yield, quality and disease incidence of Pea (Pisum sativum). Mushroom Research 20(2): 87-94.

Akça MO, Namlı A (2015) Effects of poultry litter biochar on soil enzyme activities and tomato, pepper and lettuce plants growth. Eurasian J Soil Sci. 4(3): 161-168.

Aşık B, Kütük C (2012) Çay atığı kompostunun çim alanların oluşturulmasında kullanım olanağı. U.Ü. Ziraat Fakültesi Dergisi 26(2): 47-57.

Bayram E, Kırıcı E, Tansi S, Yılmaz G, Arabacı O, Kızıl S, Telci İ (2010) Tibbi ve aromatik bitkiler üretiminin arttırılması olanakları. Ziraat Mühendisliği VII. Teknik Kongresi, Bildiriler Kitabi-1, 11-15 Ocak 2010 Ankara. 437-457.

Beyzi E (2011) Çemen (Trigonella foenum-graecum L.)'de Farklı Fosfor Dozlarının Verim Ve Bazı Morfolojik Özellikler Üzerine Etkileri. (Yüksek Lisans Tezi). Fen Bilimleri Enstitüsü, Tarla Bitkileri Anabilim Dalı, Ankara Üniversitesi, Ankara.

Birben H, Çaycı G, Kütük C (1999) Atık mantar kompostunun Begonya (Begonia semperflorens) bitkisinin gelişimi üzerine etkisi. Türkiye III. Ulusal Bahçe Bitkileri Kongresi. 187-191. 14-17 Eylül, Ankara.

Çolak M, Baysal E, Şimşek H, Toker H, Yılmaz F (2007) Cultivation of Agaricus bisporus on wheat straw and waste tea leaves based composts and locally available casing materials Part III: Dry matter, protein, and carbohydrate contents of Agaricus bisporus. African Journal of Biotechnology 6: 2855-2859.

Debosz K, Petersen SO, Kure LK, Ambus P (2002) Evaluating effects of sewage sludge and household compost on soil physical, chemical and microbiological properties. Applied Soil Ecology 19: 237-248.

Demir Z, Gülser C (2015) Effects of rice husk compost application on soil quality parameters in greenhouse conditions. Eurasian J Soil Sci. 4(3): 185-190.

Demirtaş EI, Arı N, Arpacıoğlu AE, Özkan CF, Kaya H (2000) Atık mantar kompostu kullanımının örtüaltı domates yetiştiriciliğinde bitkinin potasyum ile beslenmesi ve verim üzerine etkisi. Tarımda Potasyumun Yeri ve Önemi, Çalıştayı. 3-4 Ekim 2000, Eskişehir. 132-138.

Erkel İ, Işık E (1990) Pleurotus ostreatus ve Pleurotus florida yetiştiriciliğinde değişik yetiştirme ortamlarının verime etkisi. Türkiye IV. Yemeklik Mantar Kongresi, Cilt: 2, Yalova, s. 121-126.

Fixon PE, West, FB (2002) Nitrogen fertilizers: meeting contemporary challenges. Ambio 31(2): 169-176.

Goli Kalanpal E, Amani N, Esmarelpour B (2015) Effect of spent mushroom compost application on growth parameters 
and macro element uptake in lettuce (lactuca sativa $1 . \mathrm{cv}$ syaho). Dept. of soil science and engineering, university of mohaghegh ardabili. Electronic journal of soil management and sustainable production 5(2): 113-129.

Gülser C, Candemir F, Kanel Y, Demirkaya S (2015) Effect of manure on organic carbon content and fractal dimensions of aggregates. Eurasian Journal of Soil Science 4: 1-5.

Gülser C, Pekşen A (2003) Using tea waste as a new casing material in mushroom (Agaricus bisporus (L.) Sing.) cultivation. Bioresource Technology 88: 153-156.

Guo M, Chorover J (2006) Leachate migration from spent mushroom substrate through intact and repacked subsurface soil columns. Waste Management 26: 133-140.

Hornok L (1992) The Cultivation of Medicinal Plants, Cultivation and Processing of Medicinal Plants, Ed: L Hornok, Budapest, 289-290.

Jordan SN, Mullen GJ, Murphy MC (2008) Composition variability of spent mushroom compost in Ireland. Bioresource Technology (99): 411-418.

Kacar B (1997) Gübre Bilgisi. Ankara Üniversitesi Ziraat Fakültesi Yayın No: 1490, Ders Kitabı: 449, Ankara.

Kacar B (2009) Toprak analizleri (Genişletilmiş İkinci Baskı). Nobel Yayın No: 1387, Nobel Yayın Dağıtım, Ankara.

Kacar B, İnal A (2008) Bitki analizleri, Cilt 1, Nobel yayını, Ankara, s. 892.

Kevseroğlu K, Özyazıcı G (1997) Azotlu gübre dozlarının çemen (Trigonella foenum-graecum L.) bitkisinin bazı tarımsal özelliklerine etkileri. Türkiye II. Tarla Bitkileri Kongresi Bildiri Kitab1, Samsun, s. 367-371.

Kizıl S, Arslan N (2003) Investigation of the effects on yield and yield components of different sowing rates in some fenugreek (Trigonella foenum-graecum L.) lines. Journal of Agricultural Sciences 9(4): Ankara.

Kropisz A (1992) Influence of Fertilization with Coposition Yield of Vegetables and Their Content of Mineral Elements. Annals of Warsaw Agricultural University 16: 9-13.

Kütük CA, Taban S, Kacar B, Samet H (1996) Etkinlikleri yönünden çay atığı ile ahır gübresi ve değişik kimyasal gübrelerin karıştırılması. Tarım Bilimleri Dergisi 2(3): 5157.

Mehta RS, Patel1 BS, Meena SS, Meena RS (2010) Influence of nitrogen, phosphorus and bio-fertilizers on growth characters and yield of fenugreek (Trigonella foenumgraecum L.) Journal of Spices and Aromatic Crops 19(1-2): 23-28.

Özdemir N, Öztürk E, Tebessüm Ö, Durmuş K, Ekberli İ (2015) Effects of organic and inorganic amendments on soil erodibility. Eurasian J Soil Sci 4(4): 266-271

Parades C, Medina E, Bustamante MA, Moral R (2016) Effects of spent mushroom substrates and inorganic fertilizer on the characteristics of a calcareous clayey-loam soil and lettuce production. Department of Agrochemistry and Environment, Miguel Hernandez University, EPS-Orihuela, ctra. Beniel Km 3.2, 03312 Orihuela (Alicante), Spain.

Pekşen A, Günay A (2009) Use of substrates prepared by the mixture of tea waste and wheat straw in Agaricus bisporus (L.) Sing. cultivation. Ekoloji 19(73): 48-54.

Pekşen A, Yakupoğlu G (2009) Tea waste as a supplement fort he cultivation of Ganaderma of lucidum. World J. Mikrobiyal Biotechnol (25): 611-618.

Pill WG. Evans TA, Garrison SA (1993) Forcing white asparagus in various substrates under cool and warm regimes. Hort Sci. (28): 996-998.

Roy S, Barman, S, Chakraborty U, Chakraborty B (2015) Evaluation of spent mushroom substrate as biofertilizer for growth improvement of Capsicum annuum L. J Appl Biol Biotechnol 3, 022-027.

Samet H (1996) Zenginleştirilerek organik gübreye dönüştürülmüş çay atığı ve çeşitli organik materyallerin etkinlikleri yönünden karşılaştırılması. (Yüksek Lisans Tezi). Ankara Üniversitesi Fen Bilimleri Enstitüsü, Toprak Anabilim Dalı, Ankara.

Siddiqui Y, Tajul MI, Sariah M (2011) Conjunctive use of compost tea and inorganic fertilizer on growth, yield and terpenoid content of Centella asiatica (L.) urban. Scientia Horticulturae.130(1): 289-295.

Söchtig H, Grabbe K (1995) The Production and Utilization of Organic-Mineral Fertilizer From Spent Mushroom Compost. Science and Cultivation of Edible Fungi Volume II, 907-915.

Vandenkoornhuyse P, Baldauf SL, Larval C, Straczek J, Young JPW (2002) Evaluation of Spent Mushroom Substrate as biofertilizer for growth improvement of Capsicum annuиm L. Science 295-2051. 